$$
\begin{aligned}
& \text { プレコートアルミニウム材の加工後耐食性 } \\
& \text { 服部 伸郎* · 谷川 正樹* . 川出 義之 ** . 興戸 正純 } * *
\end{aligned}
$$

Journal of Japan Institute of Light Metals, Vol. 58, No. 4 (2008), pp. 157-161

\title{
Corrosion resistance of pre-coated aluminum sheets after forming
}

\author{
Nobuo HATTORI*, Masaki TANIGAWA*, Yoshiyuki KAWADE*** and Masazumi OKIDO**
}

\begin{abstract}
Pre-coated aluminum sheets are superior in cost performance and productivity compared to aluminum sheets coated after press forming. Functional pre-coated aluminum sheets, with superior surface characteristics such as lubricity and corrosion resistance have been increasingly used in electrical and other industrial fields. In this paper, the function of corrosion resistance was taken up among these surface functions. And the effects of the glass transition temperatures of the films on the corrosion resistance of pre-coated aluminum sheets before and after forming were investigated. The corrosion resistances after forming of polyester pre-coated aluminum sheets with three different glass transition temperatures were investigated by salt spray test. It was found that corrosion resistances of the film with glass transition temperatures higher than the forming temperature were low. In the samples with low corrosion resistance after forming, whitening of the film was observed. The corrosion reaction resistance values after forming of polyester pre-coated aluminum sheets with three different glass transition temperatures were also measured by electrochemical impedance spectroscopy test. It was found that corrosion reaction resistance values of the film with high glass transition temperatures showed the small values after stretching. It could recognize correlation in above two test results. After forming, micro cracks could be observed only in the sample with high glass transition temperature. This micro cracks made the corrosion resistance of the samples decrease.
\end{abstract}

(Received November 7, 2007 Accepted December 17, 2007)

Keywords: pre-coated aluminum, glass transition temperature, corrosion resistance, salt spray test, electrochemical impedance spectroscopy

\section{1. 緒言}

アルミニウムは鋼材より軽く，比強度があり，熱を伝えや すいなどの特徴を有することから，多くの用途に使用されて いる。中でもエアコン用熱交換器フィン材の親水化処理のよ うに，表面処理により機能を付与した製品も広く適用されて いる。また最近ではノートパソコン用光ディスクドライブの カバーにきずや指紋が目立た妈理が施されており，これ以 外にも放熱性, 抗菌性, 非粘着性, 防污性といった表面機能 を持ったアルミニウム板が次々に開発，実用化されている。

これらの機能皮膜はプレス加工後に塗布するよりも，プレ ス加工前のアルミニウム板にあらかじめ塗布しておく方法 （プレコート法）の方がコスト，生産性の点で有利であるが, 一方，その機能がプレス加工によって損なわれないように配 慮しておく必要がある。本報ではプレコート皮膜に要求され る基本性能の一つである耐食性を取上げ，プレコートアルミ 二ウム板の絞り加工前後の耐食性について, 皮膜のガラス転 移温度の影響を調べた。本報では加工ひずみの影響を定量的 に捕らえるため，絞り加工試験に加えて一定の伸びひずみを 与えるストレッチ試験を実施し, 絞り加工試験との対応を確 認した。またひずみを受けたプレコートアルミニウム板の耐
食性を定量的に捕らえるため, 塩水噴霧試験後のレイティン グナンバ法と, 腐食反応抵抗を算出できる交流インピーダン ス法により耐食性の定量化を試みた。

\section{2. 実 験 方 法}

\section{1 供試材の作製}

供試材の作製手順を示す。材料には純アルミニウム板（板 厚 $1.2 \mathrm{~mm}$ の A1100-O）を使用した。

アルミニウム表面に残存する油分を除去するため，サーフ クリーナEC370（日本ペイント製） $1 \mathrm{vol} \%$ 水溶液を用い，浴 温 $338 \mathrm{~K}$, 浸漬時間 10 秒にて脱脂を行った後, アルサーフ 401KB-2，アルサーフ $45 \mathrm{~KB}$ (いずれも日本ペイント製）をそ れぞれ $3.6 \mathrm{vol} \%$ および $0.72 \mathrm{vol} \%$ 混合した水溶液に，浴温 308 K にて浸漬することによりりん酸クロメート処理 ${ }^{1), 2)}$ を施し た。りん酸クロメート皮膜の厚さは, 単位面積あたりの金属 クロム付着量に換算し， $0.02 \mathrm{~g} / \mathrm{m}^{2}$ となるように浸漬時間を調 整した。

次にりん酸クロメート処理したアルミニウム板の片面に, ガラス転移温度 $T g$ の異なる 3 種類のポリエステル系塗料を 乾燥皮膜厚さが $5 \mu \mathrm{m}$ となるように塗布した後, 温度 $523 \mathrm{~K}$ で 焼付けることで皮膜を形成し，供試材となるプレコートアル

*(株神戸製鋼所アルミ板研究部（† 321-4367 栃木県真岡市鬼怒ヶ丘 15)。Aluminum Sheets and Coils Research Department, Kobe Steel, Ltd. (15 Kinugaoka, Moka-shi, Tochigi 321-4367).

**名古屋大学大学院工学研究科 (名古屋市)。Department of Materials Science and Engineering, Graduate School of Engineering, Nagoya University (Nagoya-shi, Aichi). 


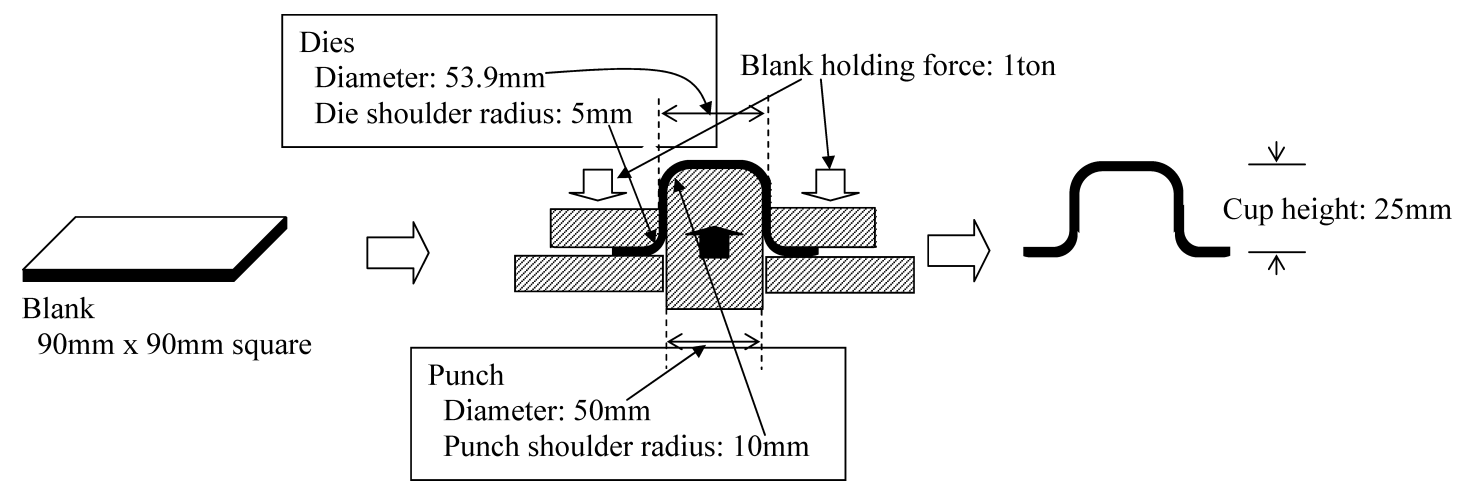

Fig. 1 Conditions of the drawing test.

ミニウム板を作製した。ここでポリエステル系塗料のガラス 転移温度は $273 \mathrm{~K} ， 313 \mathrm{~K} ， 353 \mathrm{~K}$ の 3 種類とし，図表における 塗料記号はガラス転移温度の低いほうから順に C0，C40，C80 とした。焼付け方法は，アルミニウム板がコンベアに乗って オーブンの入り口から出口へ移動する連続焼付け方式とし, 焼付け時間はオーブン内通過時間で 40 秒とした。また供試 材に貼付けたヒートラベルで確認される材料到達最高温度を 焼付け温度とした。

\section{2 加工試験}

1）絞り加工試験

作製した 3 種類の供試材に対して，直径 $50 \mathrm{~mm} \times$ 高さ 25 $\mathrm{mm}$ の円筒絞り加工を行った（Fig. 1)。ここでプレコートア ルミニウム板の皮膜形成面がカップの外側となるように加工 した。潤滑油として市販の速乾性油を使用した。加工時の室 温は $313 \mathrm{~K}$ であった。

2）ストレッチ試験

絞り加工試験は実際にプレコートアルミニウム板をプレス 加工して使用する製品の状態を模擬再現しているため，現実 に即した試験といえる。しかし一方で加工によってアルミニ ウム板や皮膜が受けるひずみ量を定量的に取扱うのが難しい。 そこで本報ではアルミニウム板や皮膜に定量的な伸びひずみ を加えることのできるストレッチ試験を合せて実施した。絞 り加工試験を模擬再現する必要から，絞り加工試験と同一の 潤滑油を皮膜に塗布した状態でストレッチ試験した。伸びひ ずみは $0 \%$ (ストレッチなし)，10\%，20\%とし，0\%のサン プルにも潤滑油の塗布は実施した。

\section{3 耐食性試験}

1）中性塩水噴霧試験

JIS Z2371 中性塩水噴霧試験に準じて試験を行った ${ }^{3), 4)} 。 す$ なわち $5 \mathrm{mass} \%$ の塩化ナトリウム水溶液を噴霧液とし，噴霧 環境温度は $308 \mathrm{~K}$ ，噴霧量は面積 $80 \mathrm{~cm}^{2}$ で 1 時間ごとに $1.5 \mathrm{ml}$ とした。また試験時間は最大 3000 時間とした。本試験は絞 り加工サンプルとストレッチ試験サンプルの両方について実 施し，いずれの場合も皮膜処理面が噴霧面となるようにした。

なおストレッチ試験サンプルについては，腐食面積率に よって腐食の程度を定量化するレイティングナンバ法に準拠 して数值化を行った ${ }^{3), 4)}$ 。

2）インピーダンス测定

耐食性の促進試験としてインピーダンス測定を実施した (Fig. 2)。ストレッチ試験サンプルに対して露出部面積が 10 $\mathrm{cm}^{2}$ となるように試験面の一部および裏面, 端面をマスキン

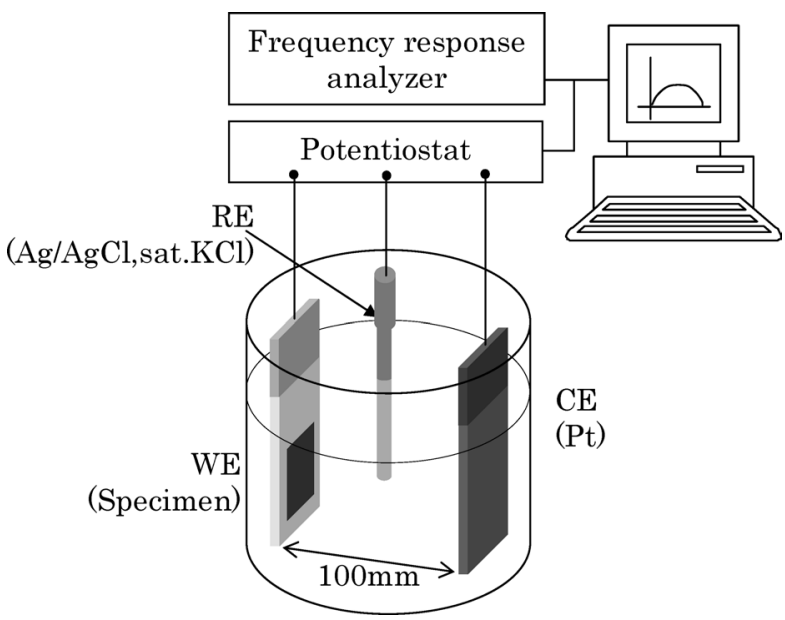

Fig. 2 Schematic view of the electrochemical impedance spectroscopy.

グして作用電極とし，対極は白金電極，参照極には銀塩化銀 電極（ $\mathrm{Ag} / \mathrm{AgCl}$, sat. $\mathrm{KCl})$ を使用した。作用電極と対極との距 離は $100 \mathrm{~mm}$ とした。自然浸漬状態において $100 \mathrm{mV}$ 幅の交流 電圧を印可した。測定周波数は $10 \mathrm{mHz}$ から $10 \mathrm{kHz}$ まで变化 させた。

周波数を変化させて得たインピーダンスの実数成分と虚数 成分を複素平面にプロットし，Fig. 3 の等価回路との関係か ら腐食反応の反応抵抗 $R_{\mathrm{ct}}$ を求めた。なお Fig. 3 の等価回路 に拈ける $R_{\mathrm{ct}}$ は作用電極表面の反応抵抗を, $C_{\mathrm{dl}}$ は電極表面に 形成される電気二重層の容量を, $R_{\mathrm{sol}}$ は電解液の溶液抵抗を 意味する。

今回 $5 \mu \mathrm{m}$ と比較的厚い膜厚を有するプレコートアルミニ ウム板が測定対象となることから, 予備試験により測定可能 条件を探索した結果, 試験浴は $\mathrm{pH}=1$ の $\mathrm{HCl}$ 溶液を使用し た。試験浴の擋汼，バブリングは行わず，大気開放状態にて 室温で測定を行った。本試験は中性塩水噴霧試験の加速試験 としての位置付けとなることから, 塩水噴霧試験に近い条件 で行うため $\mathrm{NaCl}$ 水溶液であインピーダンス測定を試みたが, 浸漬後 150 時間で屯電流がほとんど流れないため, 信頼性の ある測定結果は得られなかった。

\section{3. 実験結果および考察}

\section{1 絞り加工試験サンプルの耐食性}

中性塩水噴霧試験 3000 時間後の外観を Fig. 4 に示す。皮 

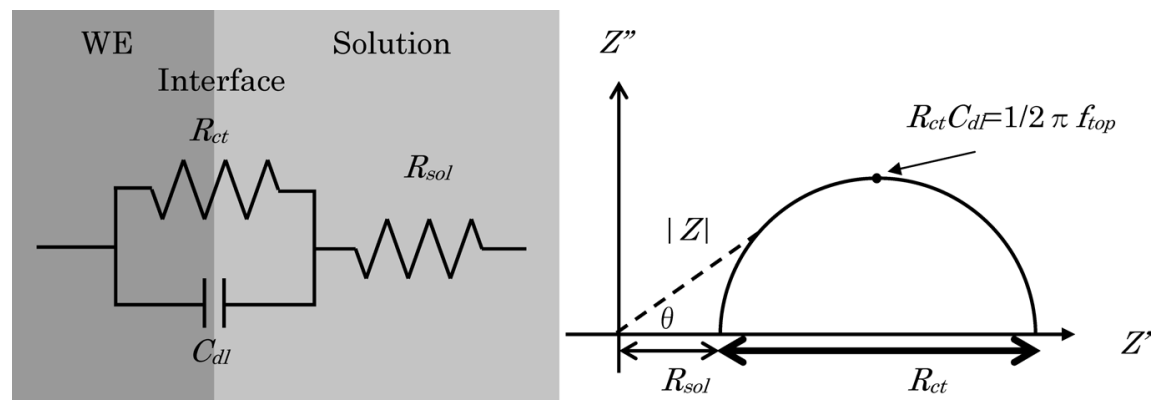

Fig. 3 Schematic view of the meaning of Cole-Cole plot and the equivalent circuit. ( $R_{\mathrm{ct}}$ : reaction resistance, $C_{\mathrm{dl}}$ : capacitance of electrochemical double layer on the electrode, $R_{\text {sol }}$ : solution resistance)

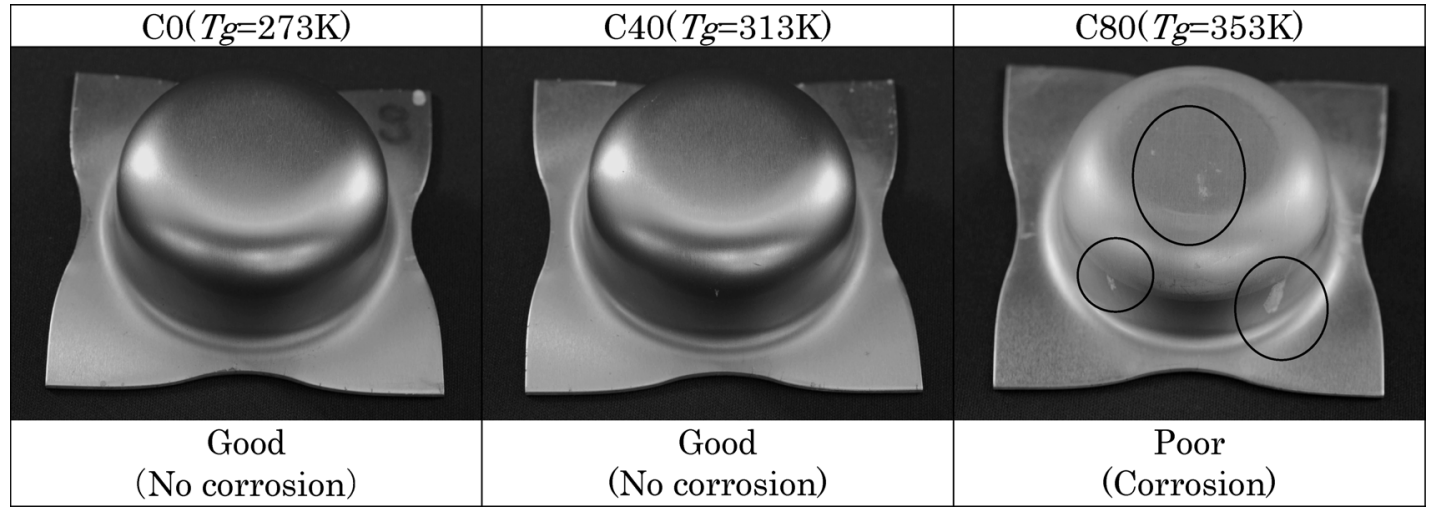

Fig. 4 Appearance of the drawn cup after $3000 \mathrm{~h}$ neutral salt spray test.
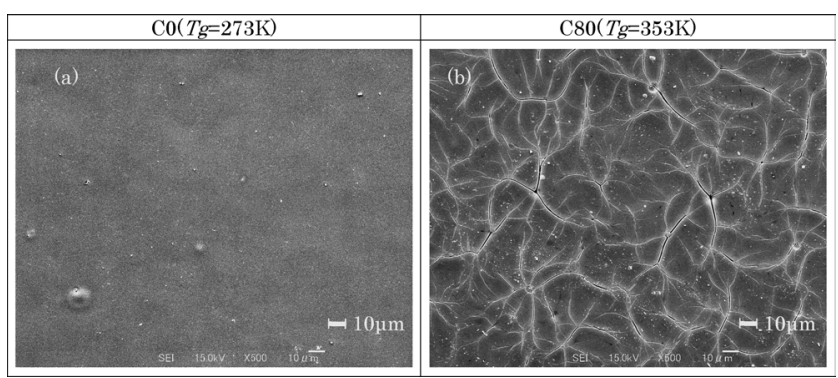

Fig. 5 SEM photographs of the coated film surface of drawn cups.

膜のガラス転移温度 $T g$ が $273 \mathrm{~K}$ の $\mathrm{C} 0$ と $313 \mathrm{~K}$ の $\mathrm{C} 40$ のサン プルには腐食が観察されなかったが，353K のC80のサンプ ルには腐食が見られた。また C80のサンプルだけは，全体的 に外観が白化した。このようにガラス転移温度の高い皮膜の 場合に加工で皮膜が白くなる挙動は既報で報告しているが,

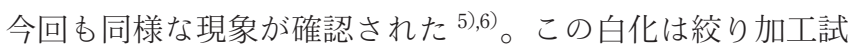
験によって皮膜に発生するミクロクラックであり， ミクロク ラックの発生メカニズムには, 皮膜のガラス転位温度とプレ ス油ならびに加工によるひずみ・変形が影響していることは 既報にて明らかにした通りである ${ }^{6)}$ 。白化が生じた C80 と白 化が生じない C0 の絞り加工サンプルについて, 皮膜のミク ロクラックの状態を Fig. 5 に示す。なお既報ではガラス転位 温度 $313 \mathrm{~K}$ のサンプルは白化したのに対し, 本報では白化が 生じなかったが，これは加工を行ったタイミングが既報は冬 場, 今回は夏場であったためによる違いである（既報の加工 温度 $283 \mathrm{~K}$, 本報 $313 \mathrm{~K}$ )。

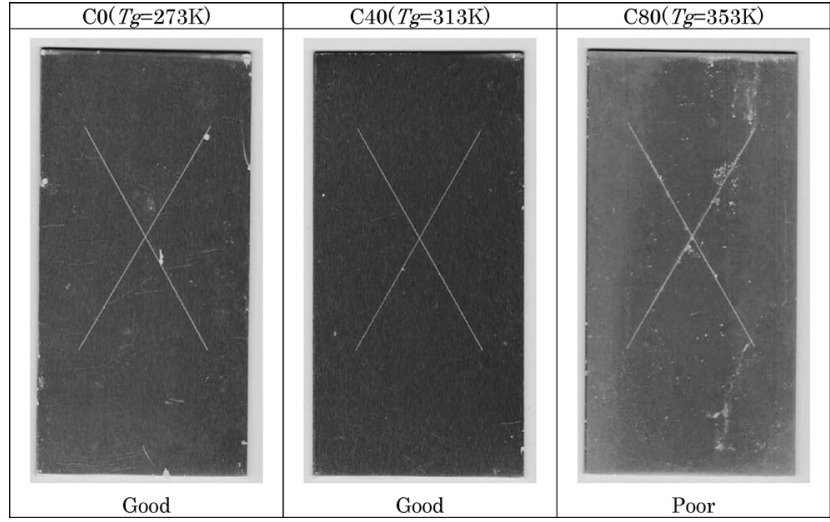

Fig. 6 Appearance of the 10\% stretched specimens after $3000 \mathrm{~h}$ neutral salt spray test.

\section{2 ストレッチ試験サンプルの耐食性}

1）中性塩水噴霧試験結果

ストレッチ量 $10 \%$ のストレッチ試験サンプルについて, 中 性塩水噴霧試験 3000 時間後の外観を Fig. 6 に示す。皮膜の ガラス転移温度が $273 \mathrm{~K}$ と $313 \mathrm{~K}$ のサンプルでは, サンプル の端面やクロスカットの近傍に腐食が発生するにとどまった が，ガラス転移温度が $353 \mathrm{~K}$ のサンプルでは端面やクロスカッ 卜近傍に限らず，その他の部位で屯腐食が発生した。腐食が 顕著なガラス転移温度 $353 \mathrm{~K}$ のサンプルでは, ストレッチ試 験後の時点で外観が全体的に白化した。ストレッチ試験によ る皮膜の白化と絞り加工試験の皮膜の白化は既報の通り基本 的に同じメカニズムである ${ }^{6)}$ 。白化の生じたサンプルが白化 の生じていないサンプルに比べて耐食性が低くなるという現 


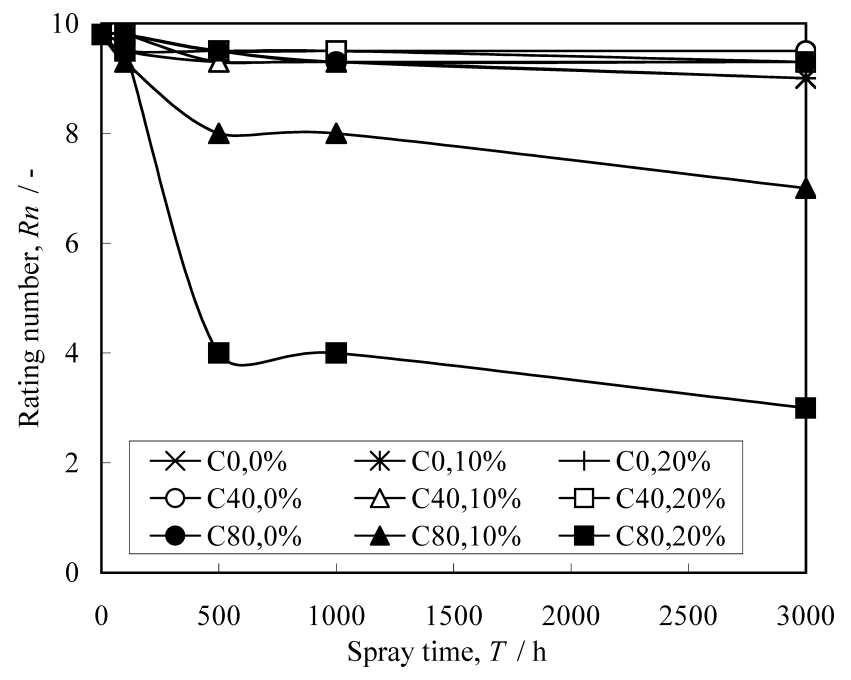

Fig. 7 Neutral salt spray test results of the stretched specimens.

象は，絞り加工試験の結果と一致する。

すべてのストレッチ試験サンプルについて中性塩水噴霧試 験による腐食状態の経時変化をレイティングナンバ法によっ て数值化した結果を Fig. 7 に示す。図中の各シンボルの説明

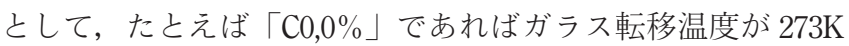
の $\mathrm{C} 0$ 皮膜を塗布した試験片を $0 \%$ ストレッチしたことを意 味する。ガラス転移温度が $273 \mathrm{~K}$ と $313 \mathrm{~K}$ のサンプルでは，ス トレッチ $0 \%, 10 \% ， 20 \%$ のいずれの場合にも耐食性の低下 は3000 時間までほとんどみられなかった。またこれらのサン プルはすべてストレッチ試験後の段階で白化は見られなかっ た。一方，ガラス転移温度が $353 \mathrm{~K}$ のンプルは，ストレッ チ量 $0 \%$ の場合，試験時間が 3000 時間の場合でも耐食性の 低下はほとんどみられなかったが，ストレッチを $10 \%$ または $20 \%$ 行ったサンプルでは試験時間 500 時間の段階ですでに耐 食性が大きく低下した。耐食性が低下した 2 種類のサンプル はストレッチ試験後にすでに白化しているサンプルであった。 以上から耐食性の著しい低下は，ストレッチによって皮膜が 白化したサンプルだけであり，皮膜の白化が耐食性を低下さ せていることがわかる。またストレッチ量が大きいほど耐食 性が低下する傾向にあった。

上記中性塩水噴霧試験 3000 時間後のストレッチ試験サン プルのうち，腐食が軽微なガラス転移温度 $353 \mathrm{~K}$ のストレッ チ $0 \%$ サンプルと, 腐食がある程度進行したガラス転移温度 $353 \mathrm{~K}$ のストレッチ $10 \%$ サンプルについて，皮膜を剥離した アルミニウム表面の顕微鏡写真を Fig. 8 に示す。ストレッチ $0 \%$ のサンプルではクロスカット部から糸状腐食が生じ始め ている様子しか見られないことから，腐食の基点がクロス カット部に限定されていることがわかる。一方，ストレッチ $10 \%$ のンプルでは, クロスカットからの糸状腐食以外に, 独立した孔食が無数に認められる。このことはクロスカット 部以外の任意の位置が腐食の起点となったことを示している。

2) インピーダンス測定結果

ストレッチ試験サンプルについて，インピーダンス試験に より求めた腐食反応の反応抵抗 $R_{\mathrm{ct}}$ を Fig. 9 に示す。中性塩

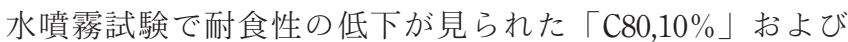
$\lceil\mathrm{C} 80,20 \% 」$ の 2 サンプルは，それ以外の 7 サンプルよりも全

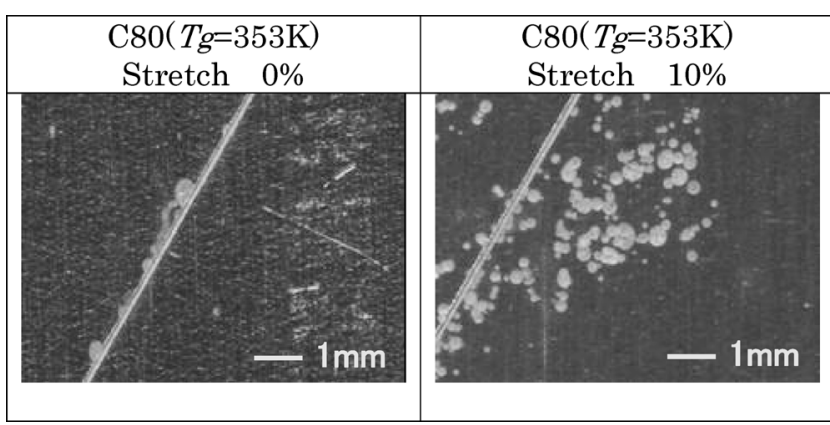

Fig. 8 Photographs of the $3000 \mathrm{~h}$ neutral salt spray test specimens after film removing.

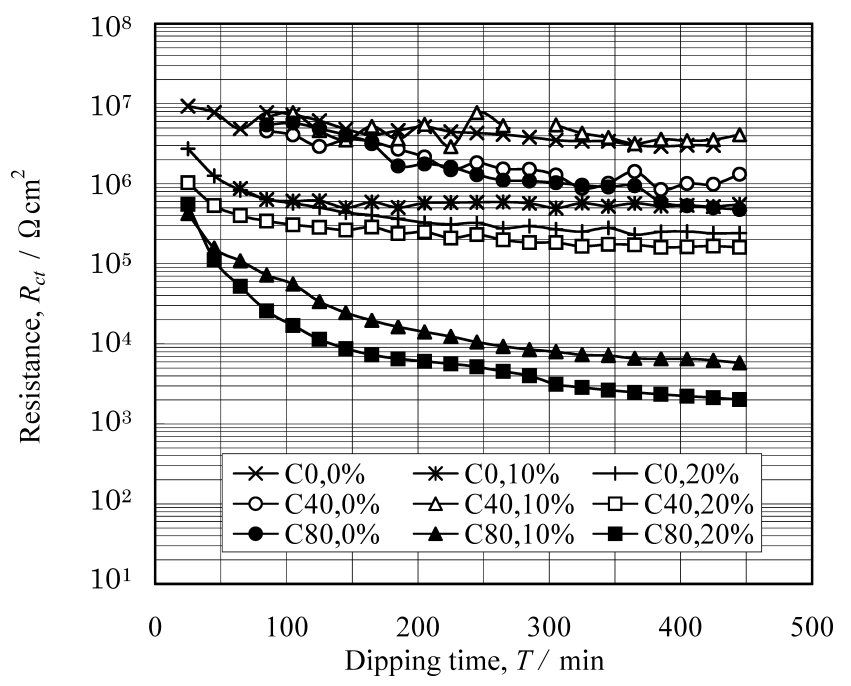

Fig. 9 Electrochemical impedance spectroscopy results of the stretched specimens.

体的に低い $R_{\mathrm{ct}}$ を示した。浸漬開始 450 分後の $R_{\mathrm{ct}}$ で比較する

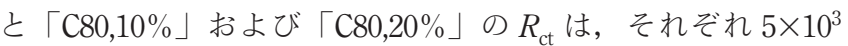
$\Omega \mathrm{cm}^{2}$ および $2 \times 10^{3} \Omega \mathrm{cm}^{2}$ であるのに対し, 残りの 7 種類の $R_{\mathrm{ct}}$ は $2 \times 10^{5} \Omega \mathrm{cm}^{2}$ から $4 \times 10^{6} \Omega \mathrm{cm}^{2}$ の範囲であったことから，両 者の間には扰よそ 2 桁程度の有意差が見られた。

$R_{\mathrm{ct}}$ が大きい 7 種類のサンプルと, $R_{\mathrm{ct}}$ が小さい 2 種類のサ ンプルについて，インピーダンスの複素平面プロット（ColeCole プロット）の例を Fig. 10 に示す。な打例を示したのは $\left\lceil\mathrm{C} 0,0 \% 」\right.$ $\%\left\lceil\mathrm{C} 80,20 \% 」 て ゙ あ る 。 R_{\mathrm{ct}}\right.$ が小さい「C $80,20 \% 」 と$

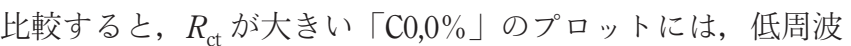
数側に半円の崩れがわずかに認められ，この崩れが $R_{\mathrm{ct}}$ に若 干の䛊差を与えている。したがって $R_{\mathrm{ct}}$ が大きい 7 種類のサ ンプル間で耐食性の優劣を単純に決めるのは難しい。しかし 半円の崩れは限定的であり，半円の崩れがほとんどない残り の 2 種類の $R_{\mathrm{ct}}$ との有意差は明確であるため, 交流インピー ダンス法から算出した $R_{\mathrm{ct}}$ は, ひずみを受けたプレコートア ルミニウム材の耐食性を十分判断できる精度を有すると考え られる。

中性塩水噴霧試験結果とインピーダンス試験結果の相関を 見るため, インピーダンス試験開始 450 分後の各サンプルの 反応抵抗值を, 中性塩水噴霧試験 3000 時間後の各サンプル のレイティングナンバに対してプロットした結果を Fig. 11 に示す。両試験の結果には相関が見られた。インピーダンス 試験を行った後のサンプルの皮膜を剥離すると, 腐食形態は 

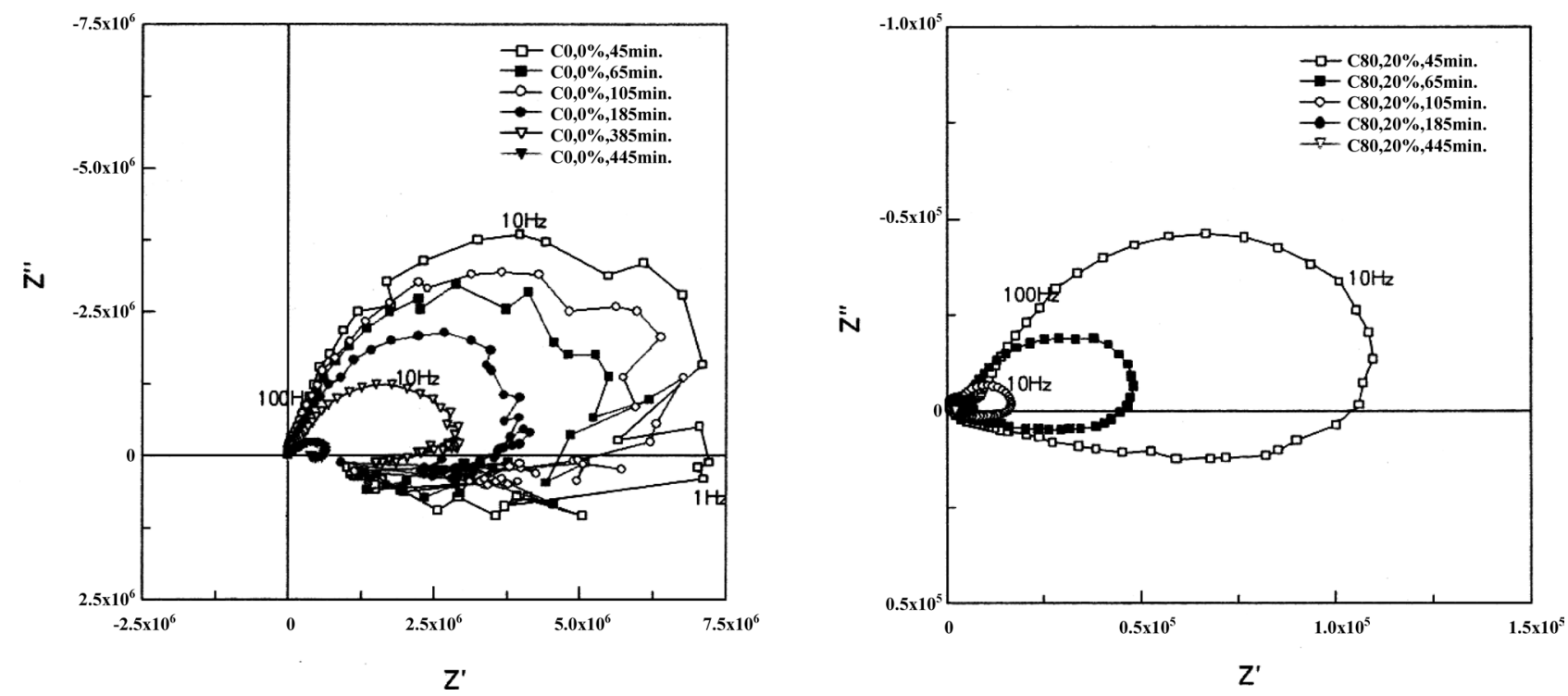

Fig. 10 Example of the Cole-Cole plot of specimens. (Left: C0 of 0\% stretching, Right: C80 of 20\% stretching)

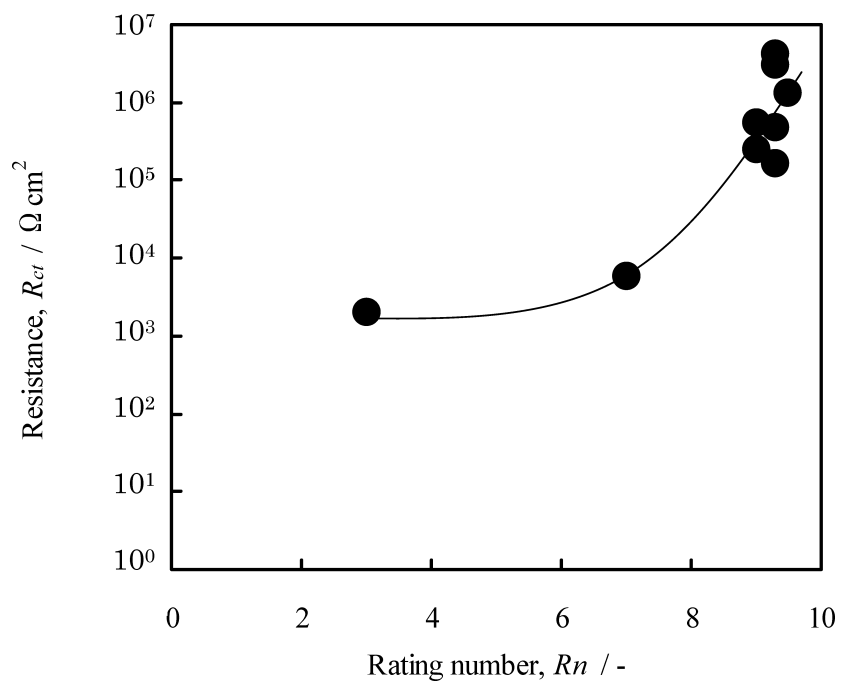

Fig. 11 Relation between the resistance and rating number.

孔食状で，中性塩水噴霧試験後の腐食形態とも一致した。イ ンピーダンス試験結果が中性塩水噴霧試験の結果と多くの点 で一致していることから，促進試験としての有効性が認めら れたものと考える。

今回試験した 3 種類の皮膜は, 加工を受ける前の健全な状 態では同等のバリヤ効果を有するため，加工前の耐食性には 差異が見られなかったが，加工を受けた際に皮膜のミクロク ラックの生じやすさはガラス転移温度によって異なるため, 皮膜のバリヤ効果がミクロクラックにより低下する割合が異 なることによって加工後の耐食性の違いが説明されるものと 考える。以上のようなメカニズムを考えると, 今回試験した ポリエステル皮膜について加工後の耐食性を高いレベルで維 持するためには，加工によって生じる皮膜のミクロクラック （目視では白化として確認できる）の発生を抑制することに ついて配慮することが重要になると結論付けられる。

\section{4. 結言}

プレコートアルミニウム材の加工後耐食性について, 調査 し以下の結果が得られた。

（1）ガラス転移温度が高い皮膜は加工を受けると白化する 傾向があるが，このように白化が生じた場合には耐食性が低 下する。

（2）絞り加工後の耐食性は, ストレッチ試験後の耐食性之 相関が認められた。ストレッチ試験ではサンプルに加えるひ ずみ量を定量的に扱いやすい, 平板で取扱えるといった利点 がある。

（3）ストレッチ試験の結果, ガラス転移温度の高い皮膜の 耐食性は, ストレッチ量, すなわち加工ひずみ量が大きくな るほど，より低下することがわかった。

（4）インピーダンス試験によって得られた反応抵抗は, 中 性塩水噴霧試験後の耐食性と相関が認められた。また試験後 の腐食形態なども一致しており, 今回の試験ではインピーダ ンス試験が中性塩水噴霧試験の促進試験として有効であっ た。

（5）今回試験したガラス転移温度が 3 水準のポリエステル 皮膜の間には, 加工前の健全な状態での防食性能に差は認め られなかった。加工後耐食性の違いは, 加工によって生じる 皮膜のミクロクラックの生じやすさで説明できると考えられ る。

\section{参考文献}

1) J.A.Treverton, N.C.Davies: Metals Technology, 4 (1977), 480-489.

2）金子秀昭：実務表面技術，35，No.6（1988），283-289.

3）JIS ハンドブック「塗料」, 29 (1993), 143-145.

4) http://www.jisc.go.jp/

5）服部伸郎, 谷川正樹, 興戸正純：軽金属, 56 (2006), 448-453.

6）服部伸郎，谷川正樹，興戸正純：軽金属，57（2007），228-233. 